\title{
Adversity Quotient Effect of Achievement and Its Impact on Student Entrepreneurship Intentions
}

\author{
Eded Tarmedi, Rizqita Qiyaski Buhari, Hari Mulyadi \\ Fakultas Pendidikan Ekonomi dan Bisnis \\ Universitas Pendidikan Indonesia \\ Bandung, Indonesia \\ tarmedi@upi.edu
}

\begin{abstract}
The increasing number of unemployed in Vocational High School graduates into employment is a big issues in Indonesia. Entrepreneurship education is carried out as a solution that aims to develop students to have an entrepreneurial spirit and entrepreneurial intentions. Student's Adversity Quotient is expected to assist in obtaining high achievement and success for entrepreneurial activities. This study aims to obtain findings regarding how much the influence of Adversity Quotient on learning achievement as well as their impact on entrepreneurial intentions for Vocational Senior High School student in Bandung. This type of research is descriptive and verificative, and the method used is explanatory survey with random sampling technique of 214 respondents. Data analysis technique used is a simple linear regression with SPSS 20.0 for Windows. Results obtained in the study stated that there is positive but not significant between the Adversity Quotient of learning achievement and influence given to the intention of entrepreneurship learning achievement. Adversity Quotient overall effect on learning achievement impact on entrepreneurial intentions are not significant.
\end{abstract}

Keywords- Adversity Quotient, academic achievement, entrepreneurial intentions

\section{INTRODUCTION}

Hisrich, Peter and Shepherd [1] state that entrepreneurship is poses the creation of something new which is on the value of using the time and effort necessary, to bear the financial risk, physical, and social risks that accompany, receive a monetary reward that produced as well as personal satisfaction and success.

The concept of entrepreneurship education in general stressed to a creation of a knowledge, attitude to the skills of an individual to perform an entrepreneurial activity. Entrepreneurship education is inseparable from entrepreneurial learning. Entrepreneurial learning is a process in which individuals strive continuously to develop knowledge about the field of entrepreneurship throughout their professional lives [2].

Student success in learning depends on how students cope and confront difficulties. Not all students are able to get through the difficulties and challenges in the learning process, of course, this will affect the achievement of student achievement. Difficulty learning in the academic field shows on their failures academic achievement in accordance with its intended capacity. The success of student learning is influenced by the level of intelligence of students. Intelligence is seen as something relative, because the intelligence of each student has a different level. Intelligence related to how students in overcoming and facing difficulties in the learning process are the type of intelligence that is used is the Adversity Quotient [3]. Adversity Quotient theory is a theory proposed by Paul G. Stolz in 1997, the theory aims to bridge between the intelligence quotient and emotional intelligence. Stoltz [4] explains that the IQ and EQ is not enough to be a benchmark that will predict the success of a person, in which a person with an IQ and EQ are good but do not have a high fighting spirit and ability to respond to adversity is good in itself, then the second it would be futile.

Stoltz [5] describes that Adversity Quotient as intelligence to face the difficulties and the ability to survive in a variety of challenges faced and transform this challenge into an opportunity. Adversity Quotient has an effect on performance, knowledge, creativity, productivity, motivation, risk taking, and successes in work and entrepreneurship activities faced. Adversity Quotient predict the achievement of an individual in doing an activity. Hetzel and Stranke [6] explains that the process of developing AQ students in the context of learning is done by giving the concept, material and challenging task, where the concept, content and work that increase the level of concentration greater understanding of the concept that makes heighten cognition and emotions of students.

Zhou Huijuan [7] states that the success rate of students in the learning activities are determined by the Adversity Quotient owned by each student. Additionally, Cornista [8] suggests that students with high level of Adversity Quotient has an excellence in achievement, where the Adversity Quotient effect on learning achievement attained by students. Adversity Quotient play a role in providing an overview to the individual with regard to how far the individual is able to survive the adversity and were able to overcome them.

Paul G. Stoltz [9] explains that the Adversity Quotient has an effect on performance, knowledge, creativity, productivity, motivation, risk taking, perseverance, endurance, behavior, responses to change and the level of success obtained individual. In addition, the Adversity Quotient were able to predict individuals who have the potential to conduct their activities beyond expectations, and who will give up or fail. Students which have Adversity Quotient are expected to have 
the ability to capture business opportunities as it has the ability to bear the risk, orientation of opportunity or initiative, creativity, self-reliance and resource mobilization. The ability to have an influence on the desire for high achievement and conduct entrepreneurial activities. Without the Adversity Quotient high concern students will experience frustration and uncertainty in the future entrepreneurs through the process. Rola Angga Lardika [10] points out that increased Adversity Quotient students in the school can be made by applying the method and model of problem-solving and inquiry learning model. Muhammad Shohib [11] stated that the increase of Adversity Quotient, especially in relation with student achievement in entrepreneurial activity can be done by implementing entrepreneurship programs such as seminars, training and practice of entrepreneurship.

Stoltz [12] states that the Adversity Quotient has four dimensions commonly abbreviated to CO2RE namely: Control, Ownership and Origin, Reach and Endurance. Faris Humami, Amat M. and Sumarli [13] states that students with high Adversity Quotient has advantages in achievement and Adversity Quotient affect the improvement of learning achievement.

The learning achievement can not be separated from learning, where learning is a process and achievement is the result of the learning process. Learning activities is successful if it can achieve optimal results. Additionally, Saiful Djamarah [14] which states that learning achievement is the educational assessment of students' progress in all things learned in school-related knowledge or skills / skill stated after the results of the research. Nana Sudjana [15] states that learning achievement is measured based on three areas, namely: 1) cognitive, 2) affective, and 3) psychomotor domains.

Craft and Entrepreneurship course in Senior Vocational High School can be classified as -transience knowledgeknowledge that help students to develop knowledge and life skills-based arts and technology-based economy. The scope of the subject consist of four strands, namely craft, engineering, aquaculture and processing. Mahardhika S. Kusumawardani and Umi R [16] states that the achievement of learning entrepreneurial intention and motivation can improve vocational students in conducting entrepreneurial activity.

Ajzen [17] says that the intention is a powerful predictor of how people behave in certain situations as well as virtually every human behavior is preceded by their intention to behave. How strong is the intention of a person displays a behavior indicated by ratings someone (subjective probability) whether he will perform or not perform the behavior. Intention was measured by asking someone to put himself in a continuum that is subjective dimension that includes the relationship between individual behaviour. Theory of Planned Behavior [18] states that the intention is measured by three determinants as follows: 1) The attitude of behaving, 2) subjective norm; and 3) perceived behavior control.

Vocational Senior High School (SMK) preparing students to become productive human beings who are able to work independently with the provision of practical skills and work experience (on-the-job training) have been obtained during the process of vocational education. Vocational education in the process of working together with the industry through the Industrial Work Practices (Prakerin) or internships in companies related cooperation. Vocational graduates armed with practical vocational competence, should be able to apply their knowledge and skills in the work up to the stage to create jobs itself as entrepreneurs than other high school graduates. In fact, SMK graduates have unemployment rates was high at $9.05 \%$ of the total number of unemployed educated in Indonesia by August 2015.

SMKN 2 Bandung as vocational institutions are required to prepare graduates ready and able to work independently trying to create jobs. Entrepreneurship education through subjects craft and Entrepreneurship is a solution implemented by the government in reducing unemployment by educating vocational students become entrepreneurs. Mastery and understanding of the material on the craft and entrepreneurship in students can be seen from the value obtained by the student. Obtaining the average student scores below $25 \% \mathrm{KKM}$, that number is greater than the target teachers Craft and Entrepreneurship subjects that is $10 \%$. Such conditions affect the level of entrepreneurship intention of the students, in which students obtain N 2 Bandung that low achievement in craft and entrepreneurship subjects have indicated the intention to undertake entrepreneurial activities in the future is low. It is seen from the data of Industrial Relations (Hubin) N 2 Bandung, where the percentage of the intention of the Karis as an entrepreneur by $7 \%$.

The purpose of this research study is to be achieved, namely the influence of Adversity Quotient on learning achievement and effect to the intention entrepreneurship learning achievement in class XI N 2 Bandung.

\section{RESEARCH METHODS}

The unit of analysis as respondents of this study is a Vocational Senior High School Grade XI student in Bandung, West Java, Indonesia. Therefore, it will be investigated the influence of adversity quotient on the learning achievement and it's implication on entrepreneurship intention of the students. This research was done in less than one year, then the method used is cross sectional method, the collection of information on the subject of research is only done once in a period of time, so this study is a one-shot or cross sectional. This study was conducted from February to October 2015.

The population of this study were all students of class XI N 2 Bandung in 2015 as many as N: 420 students. Sampling using simple random sampling of the population, and by using the formula Slovin obtained a sample of 204 students.

\section{RESULT AND DISCUSSION}

From the results of the calculation of the coefficient of determination for the Adversity Quotient (X) to the learning achievement (Y) is $2.46 \%$. In other words, learning achievement is influenced by Adversity Quotient by $2.43 \%$ while $97.57 \%$ are influenced by other factors. Furthermore, the results of the calculation coefficient of determination for achievement (Y) to the entrepreneurship intention $(\mathrm{Z})$ is $2.10 \%$. In other words, entrepreneurial intentions are 
influenced by learning achievement by $2.10 \%$ while $97.90 \%$ are influenced by other factors. Here is a recapitulation of
Adversity Quotient influence on learning achievement and its impact on entrepreneurial intentions.

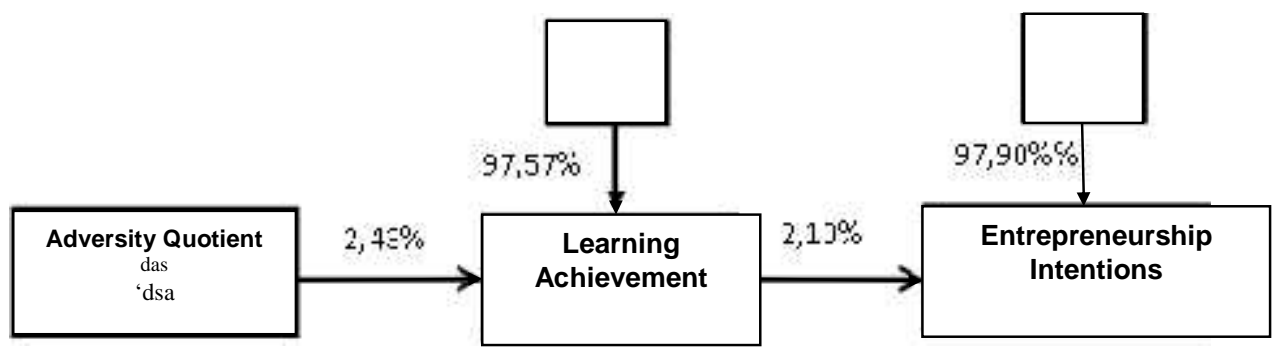

Fig. 1. Adversity Quotient Effect Of Achievement And Its Impact On Student Entrepreneurship Intentions

Based on Figure 1 shows that the influence exerted by the Adversity Quotient on learning achievement is not significant. Then, the magnitude of the influence exerted by the achievement of learning on entrepreneurship intention is not significant. The effect of learning achievement on entrepreneurial intention is positive but not significant. This is relevant with research conducted by Matore, Khairani, and Razak [19] that state the Adversity Quotient has positive impact on learning achievement but the influence exerted no significant where Adversity Quotient contribution to achievement of learning only by $0.9 \%$. Something similar was stated by Cura and Gozum [20] that the Adversity Quotient affect learning achievement by $8.18 \%$. Furthermore, research conducted by Icha S. Diyanti and Ady Soejoto [21] state that the learning achievement has positive impact on entrepreneurship intentions, but the effect to the intention of learning achievement entrepreneurship is low at $8.2 \%$.

\section{CONCLUSION}

Adversity Quotient owned class XI of SMK 2 Bandung has the effect of $2.43 \%$ on the learning achievement, while $97.57 \%$ are influenced by other factors. Correlation or relationship between Adversity Quotient and learning achievement given a score of 0,156 (positive) which means there is a very low correlation between Adversity Quotient of learning achievement. Thus it can be said that the Adversity Quotient less give a good contribution to student achievement.

The learning achievement of the students of class XI have the effect of $2.10 \%$ to the intention of entrepreneurship, while $97.90 \%$ are influenced by other factors. Correlation or relationship between learning achievements with the intention of entrepreneurship given a score of 0,145 (positive) means that there is a very low correlation between learning achievement and entrepreneurial intentions. Thus, the contribution of learning achievement in improving students' entrepreneurial intentions are small.

\section{REFFERENCES}

[1] Hisrich, P. Robert, Michael P. Peter dan Dean A. Shepherd. Entrepreneurship $7^{\text {th }}$ Ed. Jakarta: Salemba Empat, 2008, p10.

[2] Politis, Diamanto. The Process of Entrepreneurial Learning: A Conceptual Framework. Journal of Entrepreneurship Theory and Practice (ET\&P), 2005, p399-424.

[3] Supardi. Pengaruh Adversity Quotient Terhadap Prestasi Belajar Matematika. Jurnal Formatif, 3(1), 2013, p61-71.
[4] Stoltz, Paul G. Adversity Quotient (terjemah): Mengubah Hambatan Menjadi Peluang. Jakarta: PT. Grasindo, 2000, p13.

[5] Stoltz, Paul G. Adversity Quotient (terjemah): Mengubah Hambatan Menjadi Peluang. Jakarta: PT. Grasindo, 2000, p9.

[6] Hetzel, June, Tim Stranske. The IQ, EQ, AQ, and SQ Elements of Effective Pedagogy. CSE Volume 10, Number 3, 2007, p.7.

[7] Huijuan, Zhou. The Adversity Quotient and Academic Performance Among College Student at St. Joseph's College, Quezon City.(Thesis). Faculty of The Departments of Art and Sciences. St Joseph's College, 2009, p65.

[8] Cornista, Guillian Alaine L.(2013). Adversity Quotient and Achievement Motivation of Selected Third Year and Fourth Year Psychology Students of De La Salle. (Thesis). The Faculty of the College of Education, Arts and Sciences, De La Salle Lipa, 2013, p8-9.

[9] Stoltz, Paul G. Adversity Quotient (terjemah): Mengubah Hambatan Menjadi Peluang. Jakarta: PT. Grasindo, 2000, p8-9.

[10] Rola Angga Lardika. Pengaruh Model Pembelajaran Inquiry Dalam Pendidikan Jasmani Terhadap Tingkat Adversity Quotient Siswa. (Thesis) FPS. Universitas Pendidikan Indonesia, 2014, p83.

[11] Muhammad Shohib. Adversity Quotient dengan Minat Entrepreneurship. Jurnal JIPT Vol. 01, No. 01, 2013, p32-38.

[12] Stoltz, Paul G. Adversity Quotient (terjemah): Mengubah Hambatan Menjadi Peluang. Jakarta: PT. Grasindo, 2000, p124.

[13] Humami, Faris, Amat M, dan Sumarli. Pengaruh Model Pembelajaran Number Heads Together (NHT) dan Adversity Quotient Terhadap Prestasi Belajar Mata Pelajaran Mesin Konversi Energi. Jurnal Teknologi dan Kejuruan, Vol. 37, No.2, 2014, p119-128.

[14] Djamarah, Syaiful Bahri(2006). Psikologi Belajar. Jakarta: Rineka Cipta, 2006, p24.

[15] Sudjana, Nana. Dasar-dasar Proses Belajar Mengajar. Bandung: Sinar Baru Algasindo, 2005, p22.

[16] Mahardhika S. Kusumawardani dan Umi R.(2012). Pengaruh Prestasi Praktik Kerja Industri dan Prestasi Belajar Kewirausahaan Terhadap Minat Berwirausaha Siswa Kelas XII Teknik Audio Video SMK Muhammadiyah 1 Sukoharjo Tahun Ajaran 2011/2012. Universitas Negeri Yogyakarta, 2012, p89.

[17] Ajzen, Icek. Attitudes, Personality and Behaviour, Second Edition. London: Open University Press, 2005, p124.

[18] Ajzen, Icek. Attitudes, Personality and Behaviour, Second Edition. London: Open University Press, 2005, p181-182.

[19] Matore, M E E, A. Z. Khairani dan N.A Razak(2015). The Influence of $\mathrm{AQ}$ on the Academic Achievement among Malaysian Polythnic Students. International Education Studies. Vol.8, No. 6, p 69-74.

[20] Cura, J. M., \& Gozum, J. L. (2011). A correlational study in the Adversity Quotient ${ }^{\circledR}$ and the mathematics achievement of sophomore students of College of Engineering and Technology in Pamantasan ng Lungsod ng Maynila.. (Thesis). University of the City of Manila, Manila, Philippines).

[21] Diyanti, Icha S. dan Ady Soetojo(2013). Pengaruh Hasil Belajar Mata Pelajaran Kewirausahaan dan Lingkungan Keluarga Terhadap Minat Berwirausaha Siswa SMK GEMA 45 Surabaya. Jurnal Pendidikan Ekonomi (JUPE). Vol. 1, No. 3. p1-18. 